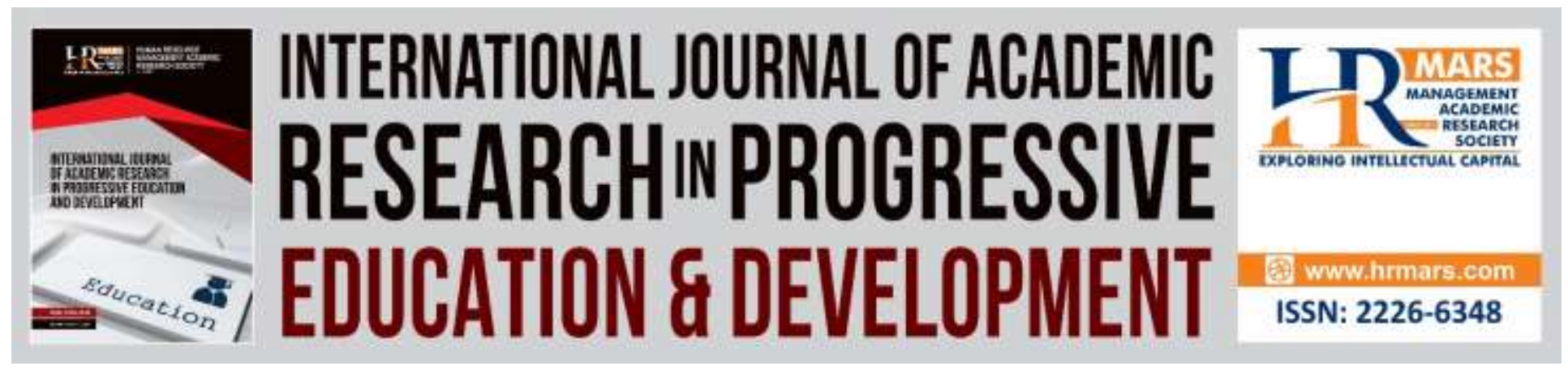

\title{
The Effectiveness of using Twitter Application in Teaching Pedagogy: A Meta-Synthesis Study
}

Hairul Faiezi Bin Lokman, Nurfaradilla Binti Mohamad Nasri \& Fariza Binti Khalid

To Link this Article: http://dx.doi.org/10.6007/IJARPED/v8-i2/5696

DOI: $10.6007 /$ IJARPED/v8-i2/5696

Received: 03 March 2019, Revised: 18 April 2019, Accepted: 30 April 2019

Published Online: 06 May 2019

In-Text Citation: (Lokman, Nasri, \& Khalid, 2019)

To Cite this Article: Lokman, H. F. Bin, Nasri, N. B. M., \& Khalid, F. B. (2019). The Effectiveness of using Twitter Application in Teaching Pedagogy: A Meta-Synthesis Study. International Journal of Academic Research in Progressive Education and Development, 8(2), 205-212.

Copyright: (C) 2019 The Author(s)

Published by Human Resource Management Academic Research Society (www.hrmars.com)

This article is published under the Creative Commons Attribution (CC BY 4.0) license. Anyone may reproduce, distribute, translate and create derivative works of this article (for both commercial and non-commercial purposes), subject to full attribution to the original publication and authors. The full terms of this license may be seen

at: http://creativecommons.org/licences/by/4.0/legalcode

Vol. 8(2) 2019, Pg. 205 - 212

http://hrmars.com/index.php/pages/detail/IJARPED

JOURNAL HOMEPAGE

Full Terms \& Conditions of access and use can be found at http://hrmars.com/index.php/pages/detail/publication-ethics 


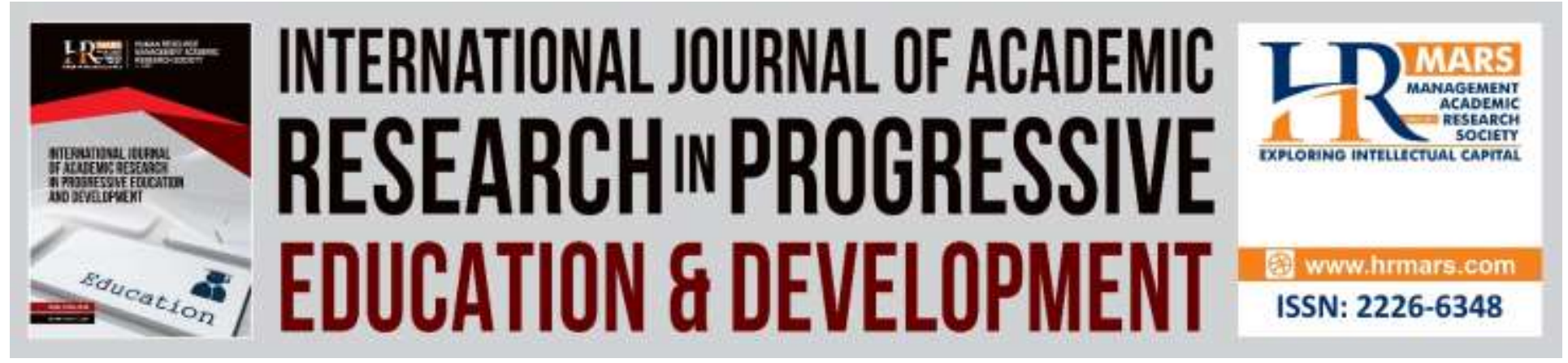

\title{
The Effectiveness of using Twitter Application in Teaching Pedagogy: A Meta-synthesis Study
}

\author{
Hairul Faiezi Bin Lokman, Nurfaradilla Binti Mohamad Nasri \\ \& Fariza Binti Khalid \\ Universiti Kebangsaan Malaysia, Malaysia
}

\begin{abstract}
In the new era of the borderless world, the development of pedagogical learning is growing and expanding progressively. Educators have diversified teaching methods to create interactive learning experiences. Twitter application is part of a social media network that is used by people every day. In the education world itself, Twitter application has been widely used in teaching pedagogy. Thus, this study is conducted to examine the effectiveness of using Twitter application in the teaching and learning process at low to high education level. Using a meta-synthesis study, 9 articles from 2012 until 2017 were selected. The findings are presented through themes derived from the synthesis of selected articles to elucidate the objectives of the study. Through the synthesis of articles that have been done, the Twitter application has given a good impact in the teaching and learning process. It has been able to increase the learning motivation and facilitate the understanding of a learning process. In addition, it can also create collaborative learning as well as create interaction within a learning process as students can generate ideas from the information sources that are easily accessible in this app. As a result, Twitter application has facilitated the management process of teaching to educators as well as helping to improve student academic achievement.
\end{abstract}

Keywords: Pedagogy, Twitter Application, Meta Synthesis

\section{Introduction}

Information technology has become the basis in the development of pedagogical learning in the 21st century (Yolanda \& Marcelle, 2018). The development of the use of information technology can be seen through various methods and learning styles that are diversified to students starting from low to upper level (Mariona \& Moises, 2018). Among the methods employed by educators is the use of social media as a tool in assisting the teaching and learning process (Lokman, Yasin \& Khalid, 2018).

The use of social media such as Twitter, Facebook, Instagram and many other social media applications have made reference to new pedagogical learning in today's teaching method 
(Chawinga, 2016). Education curriculum has changed the horizon from teacher-centered to student-centered (Hisham \& Nasruddin, 2016). The use of Twitter applications in the teaching and learning process has long been practiced (Tur, Marin \& Carpenter, 2017) since the Twitter application was introduced in 2006 (Twitter, 2017).

The Twitter application will display online information where the user sends and interacts via "tweet" messages (Twitter, 2017). One of the benefits of Twitter is that anyone can access and view the messages sent if the messages are set as public status without needing a Twitter account. If a message or material posted to Twitter is fascinating, the amount of "tweets" viral will increase through the "reTweet" function which rapidly spread the material (David, 2014).

\section{Purpose and Objective of the Research}

This study aims to look at some recent studies on the use of specialized Twitter application in the education field. The objective of the study is to examine the effectiveness of using Twitter application in the development of teaching pedagogy.

\section{Research Methodology}

This study applied a meta-synthesis study of several selected articles. Meta-synthesis study can provide extensive information and insights on selected issues (Haas \& Springer, 1998). Four article search agents were used, namely Scopus, Ebschost, Jstor and Google Scholar. Article search was done around 2012 until 2017 using three keywords: Twitter, Twitter in education and effectiveness of using Twitter in education. The group of students studied was ranked from low to the highest level of education. 
INTERNATIONAL JOURNAL OF ACADEMIC RESEARCH IN PROGRESSIVE EDUCATION AND DEVELOPMENT

Vol. 8, No. 2, 2019, E-ISSN: 2226-6348 @ 2019 HRMARS

\section{Research Findings}

After article screening, there were 43 appropriate articles which related to Twitter application in pedagogical practice. However, only ten articles were suitable to be selected in this study focusing on the research objective. The list of selected articles is as below:

Table 1: List of articles and synthesis reviews

\begin{tabular}{|c|c|c|c|c|}
\hline Bil & Author & Title & $\begin{array}{l}\text { Year / } \\
\text { Country }\end{array}$ & Synthesis reviews \\
\hline 1. & $\begin{array}{l}\text { Shawneen } \\
\text { M. } \\
\text { Gonzalez, } \\
\text { Cynthia C. } \\
\text { Gadbury- } \\
\text { Amyot }\end{array}$ & $\begin{array}{l}\text { Using Twitter for } \\
\text { teaching and } \\
\text { learning in an Oral } \\
\text { and Maxillofacial } \\
\text { Radiology Course }\end{array}$ & $\begin{array}{l}2016 \text { / } \\
\text { United } \\
\text { States }\end{array}$ & $\begin{array}{l}\text { i. This study was carried out to students } \\
\text { of Dental Radiology courses } \\
\text { (Maxillofacial Radiology courses) } \\
\text { ii. Assisted in increasing oral } \\
\text { understanding in Radiology subjects. } \\
\text { iii. Twitter became a source of simple } \\
\text { and useful learning information and } \\
\text { interaction medium }\end{array}$ \\
\hline 2. & $\begin{array}{l}\text { Ilker Yakin } \\
\text { \& Hasan } \\
\text { Tinmaz }\end{array}$ & $\begin{array}{l}\text { Using Twitter as an } \\
\text { instructional tool: } \\
\text { A case study in } \\
\text { higher education }\end{array}$ & $\begin{array}{l}2013 \text { / } \\
\text { Turkey }\end{array}$ & $\begin{array}{l}\text { i. This study was conducted in } \\
\text { Computer Application course in the } \\
\text { Social Science course. Twitter was } \\
\text { used to improve learning } \\
\text { comprehension } \\
\text { ii. Student ideas expanded with Twitter } \\
\text { iii. Twitter improved the effectiveness of } \\
\text { a learning course } \\
\text { iv. Students communicated easily and } \\
\text { efficiently with each other while } \\
\text { participating in discussion on Twitter } \\
\text { about their perspective and } \\
\text { experience, and students overcome } \\
\text { their fears and became part of the } \\
\text { classroom community }\end{array}$ \\
\hline 3. & $\begin{array}{l}\text { Gemma } \\
\text { Tur, } \\
\text { Victoria I } \\
\text { Marin \& } \\
\text { Jeffrey } \\
\text { Carpenter }\end{array}$ & $\begin{array}{l}\text { Use of Twitter in } \\
\text { higher education } \\
\text { in Spain and the } \\
\text { United States }\end{array}$ & $\begin{array}{l}2017 \text { / } \\
\text { United } \\
\text { States \& } \\
\text { Spain }\end{array}$ & $\begin{array}{l}\text { i. Studies were conducted on students } \\
\text { of the Degree of Education at } \\
\text { University of Spain and United States. } \\
\text { ii. Twitter has helped to integrate ideas } \\
\text { for courses and gained information } \\
\text { about learning through Twitter } \\
\text { search agents } \\
\text { iii. Twitter was used as a forum medium } \\
\text { and easy conversations between } \\
\text { students and lecturers }\end{array}$ \\
\hline
\end{tabular}


INTERNATIONAL JOURNAL OF ACADEMIC RESEARCH IN PROGRESSIVE EDUCATION AND DEVELOPMENT

Vol. 8, No. 2, 2019, E-ISSN: $2226-6348$ @ 2019 HRMARS

\begin{tabular}{|c|c|c|c|c|c|}
\hline & & & & iv. & $\begin{array}{l}\text { Short Twitter format has helped to } \\
\text { summarize the main idea }\end{array}$ \\
\hline 4. & $\begin{array}{l}\text { Winner } \\
\text { Dominic } \\
\text { Chawinga }\end{array}$ & $\begin{array}{l}\text { Teaching and } \\
\text { learning } 24 / 7 \\
\text { using Twitter in a } \\
\text { university } \\
\text { classroom: } \\
\text { Experiences } \\
\text { from a developing } \\
\text { country }\end{array}$ & $\begin{array}{l}2016 \text { / } \\
\text { Malawai }\end{array}$ & iii. & $\begin{array}{l}\text { Twitter encouraged student- } \\
\text { centered learning } \\
\text { Students shared and discussed } \\
\text { course content and learning beyond } \\
\text { classroom hours } \\
\text { Students used Twitter by searching, } \\
\text { generating and sharing learning } \\
\text { content and creating mutual } \\
\text { knowledge }\end{array}$ \\
\hline 5. & Chris Evans & $\begin{array}{l}\text { Twitter for } \\
\text { teaching: Can } \\
\text { social media be } \\
\text { used to enhance } \\
\text { the process of } \\
\text { learning? }\end{array}$ & $\begin{array}{l}2014 \text { / } \\
\text { London }\end{array}$ & ii. & $\begin{array}{l}\text { Twitter helped expanding the } \\
\text { involvement of university social } \\
\text { activities through information } \\
\text { The use of Twitter in learning did not } \\
\text { affect the presence of student in } \\
\text { classes. }\end{array}$ \\
\hline 6. & $\begin{array}{l}\text { Shannon B. } \\
\text { Rinaldo, } \\
\text { Debra A. } \\
\text { Laverie, } \\
\text { Suzanne } \\
\text { Tapp and } \\
\text { William F. } \\
\text { Humphrey, } \\
\text { Jr }\end{array}$ & $\begin{array}{l}\text { The benefits of } \\
\text { social media in } \\
\text { marketing } \\
\text { education: } \\
\text { Evaluating Twitter } \\
\text { as a form of } \\
\text { cognitive flexibility } \\
\text { hypertext }\end{array}$ & $\begin{array}{l}2013 \text { / } \\
\text { United } \\
\text { States }\end{array}$ & i. & $\begin{array}{l}\text { Twitter provided benefits and fun in } \\
\text { learning } \\
\text { Twitter encouraged active } \\
\text { involvement of students } \\
\text { Twitter gave more motivation, and } \\
\text { students who used Twitter got } \\
\text { higher grade than those who did not } \\
\text { use it }\end{array}$ \\
\hline 7. & $\begin{array}{l}\text { Estrella } \\
\text { Martínez- } \\
\text { Rodrigo } \\
\text { and Pura } \\
\text { Raya } \\
\text { González }\end{array}$ & $\begin{array}{l}\text { Elmicrobloggi-ng } \\
\text { en el proceso de } \\
\text { enseñanza- } \\
\text { aprendizaje. } \\
\text { Unaexperiencia } \\
\text { académica con } \\
\text { Twitter }\end{array}$ & $\begin{array}{l}2013 / \\
\text { Spain }\end{array}$ & ii. & $\begin{array}{l}\text { Twitter learning increased interest in } \\
\text { learning among students } \\
\text { Twitter provided creativity and } \\
\text { critical analysis when responding to } \\
\text { answers } \\
\text { Twitter also enhanced collaboration } \\
\text { within the group }\end{array}$ \\
\hline 8. & $\begin{array}{l}\text { Alasdair } \\
\text { Blair }\end{array}$ & $\begin{array}{l}\text { Democratising the } \\
\text { learning process: } \\
\text { The use of Twitter } \\
\text { in the teaching of } \\
\text { politics and } \\
\text { international } \\
\text { relations }\end{array}$ & $\begin{array}{c}2013 / \\
\text { No }\end{array}$ & $\begin{array}{l}\text { ii. } \\
\text { iii. }\end{array}$ & $\begin{array}{l}\text { Twitter as a means of communication } \\
\text { tool for involvement of students in } \\
\text { learning } \\
\text { Opportunity to join group discussions } \\
\text { through hashtags (\#). } \\
\text { Can implement direct } \\
\text { communication and expand social } \\
\text { relationships with more individuals, } \\
\text { especially in the field of education }\end{array}$ \\
\hline
\end{tabular}


INTERNATIONAL JOURNAL OF ACADEMIC RESEARCH IN PROGRESSIVE EDUCATION AND DEVELOPMENT

Vol. 8, No. 2, 2019, E-ISSN: 2226-6348 @ 2019 HRMARS

\begin{tabular}{|c|c|c|c|c|c|}
\hline & & & & iv. & $\begin{array}{l}\text { Can simplify and facilitate } \\
\text { information delivery as Twitter is } \\
\text { limited to } 140 \text { characters }\end{array}$ \\
\hline 9. & $\begin{array}{l}\text { Winner } \\
\text { Dominic } \\
\text { Chawinga }\end{array}$ & $\begin{array}{l}\text { Taking social } \\
\text { media to a } \\
\text { university } \\
\text { classroom: } \\
\text { teaching and } \\
\text { learning using } \\
\text { Twitter and blogs }\end{array}$ & $\begin{array}{c}\text { 2017/ } \\
\text { Malawi }\end{array}$ & $\begin{array}{l}\text { i. } \\
\text { ii. } \\
\text { iii. }\end{array}$ & $\begin{array}{l}\text { Continuous learning even outside } \\
\text { the classroom. } \\
\text { All students can interact with } \\
\text { lecturers. } \\
\text { Students will not miss the teaching } \\
\text { content because material / notes } \\
\text { and announcement will be notified } \\
\text { on Twitter early on }\end{array}$ \\
\hline 10 & $\begin{array}{l}\text { Eva } \\
\text { Kassens- } \\
\text { Noor }\end{array}$ & $\begin{array}{l}\text { Twitter as a } \\
\text { teaching practice } \\
\text { to enhance active } \\
\text { and informal } \\
\text { learning in higher } \\
\text { education: The } \\
\text { case of sustainable } \\
\text { tweets }\end{array}$ & $\begin{array}{c}2012 \text { / } \\
\text { USA }\end{array}$ & ii. & $\begin{array}{l}\text { Twitter as a medium of knowledge } \\
\text { delivery } \\
\text { The delivery of learning info using } \\
\text { Twitter is easy to remember }\end{array}$ \\
\hline
\end{tabular}

Through synthesis reviews of some articles, several themes display the effects of using Twitter application in teaching and learning process as follows:

i. Twitter application improves learning motivation

ii. Twitter application facilitates learning understanding

iii. Twitter application form collaborative learning

iv. Twitter application simplifies management of teaching and learning process

v. Twitter application improves academic achievement

vi. Twitter application forms learning interaction

vii. Twitter application is used as a source of information; and

viii. Twitter application generates ideas

\section{Research Discussion}

The Twitter application has helped to improve the motivation of learning when students are actively involved and having fun in learning process (Rinaldo et al., 2013; Rodrigo \& Gonzalez, 2013). In addition, the Twitter application has also established student understanding towards learning process as implemented in Radiology course (Gonzalez \& Gadbury-Amyot, 2016). Yakin \& Tinmaz (2013) also implemented Twitter in the Social Science course which the majority of students can easily understand the lessons presented compared to without using Twitter.

The Twitter application also created a collaborative learning concept when Twitter has been used as a forum medium and facilitates conversations between students and lecturers (Tur, Marin \& Carpenter 2017; Martínez Rodrigo \& Raya Gonzalez, 2013). Twitter also can be used by students to 
share and talk about course content during or outside the classroom by searching, generating and sharing any learning content (Chawinga, 2016). The use of hashtag symbols (\#) provides the opportunity to extend the discussion to certain topics or learning-related issue (Blair, 2013).

Research articles also prove that Twitter application can simplify the teaching and learning process when there are some unique features such as '@ - calling' and '\# hastag' which act as searching assistance on a learning topic, issue or any questions regarding learning (Yakin \& Tinmaz, 2013) whether in the classroom or outside the classroom (Chawinga, 2017). In fact, Twitter can also improve academic achievement when students are actively involved in the teaching and learning process (Rinaldo et al., 2013) as students demonstrate creativity and solve some critical analysis of learning (Rodrigo, \& Gonzalez, 2013).

In addition, the Twitter application can also create interaction in learning when Twitter pages can be followed by many users from around the world. Thus, communication and discussion can be conducted regardless of obstacles and boundaries (Gonzalez \& Amyot, 2016; Blair, 2013) when the users only need to type '\# hashtag' and enter the word without any dashes of any topics to search (Yakin \& Tinmaz, 2013 ) for sharing any views and opinions (Chawinga, 2016). Through the Twitter application, students are also able to interact easily with lecturers in learning topics everywhere regardless of time and two-way communication can be created (Chawinga, 2017).

Twitter application browsed around the world make it a very diverse source of information resources. With simple textual content, this application facilitates the delivery of simple and accurate information about a learning topic (Gonzalez \& Amyot, 2016) as well as having a search engine that facilitates the procurement process of information (Tur, Marin \& Carpenter 2017). Using this application, learning notes and materials will be uploaded by lecturers and students where the shared materials can be used as reference at all times (Chawinga 2017; Noor, 2012).

Generation of ideas can also be built through the use of Twitter application. It can gather ideas and opinions on a topic of learning. Students will then integrate the ideas (Tur, Marin \& Carpenter, 2017) and the idea generation can contribute to a comprehensive understanding (Yakin \& Tinmaz 2013).

\section{Conclusion}

In conclusion, Twitter application has given a great impression and many benefits on the pedagogical learning process in education system. The use of information technology in the 21st century has given a great impact especially to students and teachers. Social media is not only a connecting agent to the individual but if properly used social media can provide many benefits in life. This meta-synthesis study has highlighted some of the research findings related to Twitter application functions in pedagogical learning indicating that the Twitter application gives a good effect in pedagogical learning. 
INTERNATIONAL JOURNAL OF ACADEMIC RESEARCH IN PROGRESSIVE EDUCATION AND

DEVELOPMENT

Vol. 8, No. 2, 2019, E-ISSN: 2226-6348 @ 2019 HRMARS

\section{References}

Blair, A. (2013). Democratising the Learning Process: The use of Twitter in the Teaching of Politics and International Relations. Politics 33 (2),135-145. doi: 10.1111/14679256.12008.

Chawinga, W. D. (2016). Teaching and Learning 24/7 using Twitter in a University Classroom: Experiences from a Developing Country. E-Learning \& Digital Media 13 (1-2), 45-61. doi:10.1177/2042753016672381.

Chawinga, W. D. (2017). Taking Social Media to a University Classroom: Teaching \& Learning using Twitter and Blogs.International Journal of Educational Technology in Higher Education 14 (1). doi:10.1186/s41239-017-0041-6.

Evans, C. (2014). T witter for teaching: Can social media be used to enhance the process of learning?. British Journal of Educational Technology, 45(5), 902-915

Gonzalez, S. M. \& Gadbury,A. (2016). Using Twitter for Teaching and Learning in an Oral and Maxillofacial Radiology Course. Journal of Dental Education 80 (2), 149-155

Kassens-Noor, E. (2012). Twitter as a teaching practice to enhance active and informal learning in higher education: The case of sustainable tweets. Active Learning in Higher Education, 13(1), 9-21.

Llopart, M., \& Esteban-Guitart, M. (2018). Funds of knowledge in 21st century societies: Inclusive educational practices for under-represented students. A literature review. Journal of Curriculum Studies, 50(2), 145-161.

Lokman, H. F. B., Yasin, R. M., \& Khalid, F. (2017). Systematic Review and MetaAnalysis on the Effectiveness of Facebook Application in Teaching and Learning Process. International Journal of Academic Research in Business and Social Sciences, 7(4), 980-989

Martínez-Rodrigo, E. \& P. Raya-González (2013). The Microblogging in the TeachingLearning Process. Academic Experience with Twitter. Ilu 18: 139-149. doi:10.5209/rev_HICS.2013.v18.44232.

Rinaldo, S. B., D. A. Laverie, S. Tapp, \& Humphrey, Jr. W. F. (2013). The Benefits of Social Media in Marketing Education: Evaluating Twitter as a Form of Cognitive Flexibility Hypertext. Journal for Advancement of Marketing Education 21 (1): 16-26.

Tur, G., V. I. Marín, \& J. Carpenter (2017) Using Twitter in Higher Education in Spain and the USA. Comunicar 25 (51), 19-27. doi:10.3916/C51-2017-02

Yakin, I. \& H. Tinmaz (2013). Using Twitter as an Instructional Tool: A Case Study in Higher Education. Turkish Online Journal of Educational Technology. Bil. 29, 209-218.

Sealey-Ruiz, Y., \& Haddix, M. M. (2018). 21st century new literacies and digital tools as empowering pedagogies for urban youth of color. In Information and Technology Literacy: Concepts, Methodologies, Tools, and Applications (pp. 1331-1345). IGI Global. 